\title{
Association Between Quality of Antenatal Care Services by Midwife and Maternal Satisfaction in Ciputat Timur Public Health Center
}

\author{
Desty Pratiwi Marlisman, Fajar Ariyanti \\ Public Health Study Program, Faculty of Medicine and Health Sciences \\ Syarif Hidayatullah State Islamic University Jakarta, Indonesia \\ destymar@gmail.com
}

\begin{abstract}
During antenatal care services in Ciputat Timur Health Center, midwives have difficulties of time management services especially for conducting counseling and pregnant women often could not get laboratory test. The impact of that, the pregnant women could not get the antenatal care services according to the standard. This study aimed to identify association between ANC service quality by midwives and maternal satisfaction in Ciputat Timur Health Center. The method of this research was a quantitative using observational-analytical design with cross sectional approach. Study subject were 4 Midwives and 32 pregnant women which has been observed during ANC service in Ciputat Timur Health Center. The analysis showed that $53,1 \%$ the midwives compliance and $46,9 \%$ the midwives incompliance of ANC standard. In maternal satisfactory, $75 \%$ of pregnant women satisfied and $25 \%$ of pregnant women unsatisfied with ANC services. Bivariate analysis showed that the midwives compliance associated with maternal satisfaction for the quality of antenatal care $(p=0,041, O R=9,800)$. It is suggested for midwive in Ciputat Timur Health Center to increase the compliance of ANC services according to the standard of Ministry of Health Indonesia
\end{abstract}

Keywords-Antenatal Care Services; compliance; satisfaction; public health

\section{INTRODUCTION}

Good quality of Antenatal Care (ANC) service improve the maternal and child health outcome. Quality on health services was defined that service excellence and on the one side can lead the satisfaction to every patient and the other side the procedures of service conformance with ethical codes and the standards of peronal service has been established [1].

Based on the results of Basic Health Research 2010 in Indonesia, it was found that only $20 \%$ of pregnant women got services in accordance with the standards[2]. Besides, Study quality of Maternal Health Services in Indonesia 2012 reported that the quality of maternal health care has not been adequate from the provider side both hospitals and health center.

Based on the preliminary studies in the Ciputat Timur Health Center in South Tangerang, it was found that during ANC servises midwives have difficulties of time management services especially for conducting counseling and pregnant women often could not get laboratory test. The impact of that, the pregnant women could not get the antenatal care services according to the standard. In addition there were no previous measurement of maternal satisfaction of ANC services have been made in the health center.

This study aimed to identify association between ANC service quality by midwives and maternal satisfaction in Ciputat Timur Health Center.

\section{METHODS}

The method of this research was a quantitative using observational-analytical design with cross sectional approach. Study subject were 4 Midwives and 32 pregnant women which have been observed during ANC service in Ciputat Timur Health Center. Measurement of service quality by midwives using ANC observation sheets in accordance with the ANC standar form Ministry of Health of Indonesia. Measurement of maternal satisfaction use the satisfaction questioner with five dimensions of services.

\section{RESULT}

The study was conducted in 32 preganant women in Ciputat Timur Health Center. The univariate results of this study is indicated in Table I.

Table I. shows univariate analysis result in this study. Uncomply midwive with ANC standard higher $(53,1 \%)$ than comply midwive with standard $(46,9 \%)$. Pregnant women mostly satisfied with ANC services $(75 \%)$. 
TABLE I. UNIVARIATE ANALYSIS RESUlT

\begin{tabular}{|l|c|c|}
\hline Variable & $\mathbf{n}$ & \% \\
\hline $\begin{array}{l}\text { Midwive compliance } \\
\text { with ANC standard }\end{array}$ & & \\
\hline Comply & 15 & 46.9 \\
\hline Uncomply & 17 & 53.1 \\
\hline $\begin{array}{l}\text { Maternal satisfaction } \\
\begin{array}{l}\text { Unsatisfied } \\
\text { Satisfied }\end{array}\end{array}$ & 8 & 25 \\
\cline { 2 - 3 } & 24 & 75 \\
\hline
\end{tabular}

TABLE II. BIVARIATE ANALYSIS RESULT

\begin{tabular}{|c|c|c|c|c|c|}
\hline \multirow{3}{*}{ Variable } & \multicolumn{4}{|c|}{$\begin{array}{c}\text { Midwive compliance with } \\
\text { ANC standard }\end{array}$} & \multirow{3}{*}{ P value } \\
\hline & \multicolumn{2}{|c|}{ Uncomply } & \multicolumn{2}{|c|}{ Comply } & \\
\hline & $\mathbf{n}$ & $\%$ & $\mathbf{N}$ & $\%$ & \\
\hline Maternal Satisfaction & & & & & \\
\hline Unsatisfied & 7 & 87.5 & 1 & 12.5 & 0.041 \\
\hline Satisfied & 10 & 41.2 & 14 & 58.3 & \\
\hline
\end{tabular}

Bivariate analysis results can be seen in Table II. Based on the results of bivariate analysis, it is known that maternal satisfaction variable has significant relationship with midwive compliance with ANC standard with P value is equal to 0.041 .

\section{DISCUSSION}

\section{A. Midwive Compliance with ANC Standard}

The observation to process of ANC service by midwive was conducted to get the midwive compliance value. In this observation involved 8 (eight) cases of preganant women in the first trimester and 12 (twelve) pregnant women in each second and third timerster, with the number of cases observed were 32 pregnant women (cases). Observed ANC services include helper preparation (hand wash), anamnesis, general and pregnancy examination, diagnosis, intervention and implementation of activities, counceling, and midwifery documentation.

Midwive compliance on ANC services in Ciputat Timur Health Center lower than midwive uncompliance. Low midwive compliance in ANC services were on helper preparation, general and pregnancy examination, and counceling for pregnant women During ANC services midwive did not wash their hand. Besides on the general and pregnancy examination some midwive did not conduct body temperature measurement, laboratory examination, screening Tetanus Toxoid, and iron suplementation. Low counceling given by midwives also happened to the pregnant women during ANC services.

ANC service should be routine standardized and integrated for quality ANC. Wijono argues that ANC is a health service provided to prgenant women during their pregrnancy in accordance with established service standards[3]. Midwife compliance to antenatal care standard will result in quality service. Based on the previous research conducted by Marniyati
(2016) regarding quality ANC services in improving high risk detection in pregnant women by health workers in several public health centers of Palembang City also found that not all midwives comply with antenatal services standard. There are some services have not been implemented opptimally among pregnant women such as not screened TT screening and immunization, no body temperature measurement, no fetal heart rate measurement, laboratory ecaminantion and not all counceling materials given to pregnant women by midwives [4].

\section{B. Maternal Satisfaction}

Based on normality data of maternal satisfaction on ANC services in ciputat timur health center, there was 8 (eight) unsatisfied pregnant women, 24 (twenty four) satisfied pregnant women.

The pregnanat women satisfaction was measured from the maternal satisfaction perspective based on 5 dimension of quality of health care, tangible, reliability, responsiveness, assurance, and empathy. Dimension of maternal satisfaction which have satisfied the pregnant women are assurance, empathy, responsiveness and tangible. Dimension which have not satisfied the pregnant women are reliability.

In reliability deminsion, the pregnant women unsatisfied with antenatal services by midwive because midwive not wash their hand, not conduct body temperature measurement, pregnant women not get the laboratory examination, and midwive not conduct screening TT.

Patient satisfaction is a form of a person's feelings after gaining experience of service performance that has fulfill the expectations[5]. According to Hafizurrahman (2004), patient satisfaction is the important thing in health care services. This is related to the consequences of the nature of health services itself, and also related to the target and outcome of service [6].

\section{Association Between Midwive Compliance with ANC Standard and Maternal Satisfaction}

The result of this research show that the satisfied pregnant women more on the midwive which have comply with ANC standar $(58,3 \%)$. The statistical test result show that maternal satisfaction variable have significant relationship with midwive compliance with ANC standard with $\mathrm{P}$ value is equal to 0.041 .

The result of previous research by Maulana also show that there was a relationship of compliance with the satsfaction of pregnant women in health center ini Jambi [7]. Another research by Hikma in Luwu distric South Sulawesi also show that quality of midwives delivery service had positive association with maternal satisfaction [8].

The quality service is a sympathetic, dicipline, responsible and attentive service to every service given so as to give satisfaction for the services provided. Kotler (1997) defined, satisfaction experienced by patients associated with the results of services provided by health workers [9].

Based on the result show that quality of antenatal care service had positive association with maternal satisfaction. Good Quality of antenatal care have contribution 9,8 times with maternal satisfaction for antenatal care service. 
Suggestion that can be advised is midwive in Ciputat Timur Health Center should increase the compliance of ANC services according to the standard of Ministry of Health Indonesia.

\section{REFERENCES}

[1] A. Azwar, Introduction to Health Administration. Bina Putera Aksara, 2010.

[2] Ministry of Health Republic of Indonesia, "National Report: Basic Health Research 2010,” Jakarta, 2011.

[3] D. Wijono, Quality Management of Health Services. Surabaya: Airlangga University Press, 1997.

[4] L. Marniyanti, "Qualified Antenatal Services in Increasing High Risk Detection of Pregnant Women by Health Workers at Sako, Social, Sei Baung and Sei Selincah Health Centers in Palembang City," Med. Heal., vol. 3, pp. 355-362, 2016.

[5] R. Gerson, Measurment of Customer Satisfaction. Jakarta: PPM, 2004.

[6] Hafizurrachman, "Satisfaction Measurement on Health Institution,” Indones. Med. J., pp. 282-288, 2004.

[7] Maulana, "Assessment of Maternal Satisfaction on Quality of Antenatal Services in Relation to Compliance and Characteristics of Midwives at Public Health Center in Jambi City 2011," University Indonesia, 2012.

[8] Hikma, "The Correlation Between Quality of Normal Delivery Service by Midwife with Maternity Satisfaction in Luwu District of South Sulawesi," Indones. Heal. Manag., vol. 2, 2014.

[9] P. Kotler, Marketing Management, 12th ed. Jakarta: Indeks Kelompok Gramedia, 2007. 